\title{
Youth with Disabilities are More Likely than their Peers to Engage in Hazardous Child Labour
}

Short Title: Hazardous Child Labour

Professor Eric Emerson, PhD (corresponding author: +44 (0)1297 680123;

eric.emerson@lancaster.ac.uk) ${ }^{1,2,3}$

Professor Gwynnyth Llewellyn, PhD ${ }^{1,2}$

1 Centre for Disability Research and Policy, Faculty of Health Sciences, University of Sydney, Sydney, NSW 2141, Australia

2 Centre of Research Excellence in Disability and Health, University of Sydney, Sydney, NSW 2141, Australia

3 Centre for Disability Research, Faculty of Health \& Medicine, Lancaster University, Lancaster, LA1 4YW, UK

\section{Acknowledgements}

We would like to thank the UNICEF's global Multiple Indicator Cluster Surveys (MICS) program for allowing us to use the datasets.

\section{Declaration of Interest}

The authors have no conflicts of interest to report.

\section{Funding}

This research did not receive any specific grant from funding agencies in the public, commercial, or not-for-profit sectors.

\section{Data Availability}

Data are potentially available on application through UNICEF.

Keywords

Disability, child labour, hazardous child labour 


\section{Abstract}

\section{Background}

Little is known about the extent to which children and adolescents with disabilities are exposed to child labour.

\section{Objective}

To estimate prevalence rates and adjusted rate ratios of exposure to child labour among children and adolescents with/without disability in middle- and low-income countries and to determine whether these rates vary between functional limitations associated with disability.

\section{Participants and Setting}

Nationally representative samples involving 142,499 children aged 5-14 from 15 countries.

\section{Methods}

Secondary analysis of data collected in UNICEF's Multiple Indicator Cluster Surveys.

\section{Results}

Overall children and youth with disability were not at significantly greater risk of exposure than children without disability to child labour when demographic and contextual factors were taken into account. However, children and youth with disability were at significantly greater risk of exposure than children without disability to hazardous child labour (adjusted relative risk $(A R R)=1.15(1.10-1.21), p<0.001)$. Specifically, children and youth with impairments related to poorer mental health or cognitive functioning were at significantly greater risk of exposure to hazardous child labour (e.g., ARR for learning impairment $=1.27$ 
(1.14-1.42), $\mathrm{p}<0.001)$. In contrast, children with impairments related to sensory functioning, mobility and expressive communication were at no greater risk of exposure than children with no disability.

\section{Conclusions}

Children and youth with disability are at greater risk of exposure to hazardous child labour than children with no disability in middle- and low-income countries. Responses to eradicate hazardous child labour need to take account of the situation of children and youth with disability.

Key Messages

- In any day in 2016, over 70 million children were engaged in hazardous child labour.

- Hazardous child labour puts the health and development of children at risk.

- Very little attention has been paid to the involvement of children with disabilities in hazardous child labour.

- We analysed nationally representative samples from 15 middle- and low-income countries involving 142,499 children aged 5-14.

- Children with disability were at significantly greater risk of exposure than other children to hazardous child labour (adjusted relative risk $(A R R)=1.15(1.10-1.21), p<0.001)$. Increased risk was even greater for children with impairments related to poorer mental health or cognitive functioning. 


\section{Introduction}

Article 32(1) of the UN Convention on the Rights of the Child establishes 'the right of the child to be protected from economic exploitation and from performing any work that is likely to be hazardous or to interfere with the child's education, or to be harmful to the child's health or physical, mental, spiritual, moral or social development.' The International Labour Organization (ILO) draws a distinction between child work and child labour on the basis of age-specific definitions of potentially hazardous levels of work intensity and exposure to hazardous work environments (International Labour Organization, 2017).

The ILO estimated that on any given day in 2016, 152 million children were engaged in child labour, of which 73 million were engaged in hazardous labour (International Labour Organization, 2017). Involvement in child labour is more common among boys, children not in education, children living in low-income countries and children living in poverty (International Labour Organization, 2017; Khatab, Raheem, Sartorius, \& Ismail, 2019).

While there are potential personal and social benefits to some forms of child work (Bourdillon \& Carothers, 2019), evidence suggests that child labour is associated with: poor growth and nutritional status; higher incidence of injuries, infectious and system-specific diseases, behavioural and emotional disorders; decreased coping efficacy; and lower educational attainment (Dalal, Rahman, Gifford, \& Rahman, 2015; Ibrahim, Abdalla, Jafer, Abdelgadir, \& de Vries, 2019; Kuimi, Oppong-Nkrumah, Kaufman, Nazif-Munoz, \& Nandi, 2018; Shendell, Noomnual, Chishti, Allacci, \& Madrigano, 2016; Sturrock \& Hodes, 2016). Unsurprisingly, child labour under hazardous conditions is particularly detrimental to child health (Forastieri, 1997; International Labour Organization, 2018; Posso, 2019). 
The association between disability and child labour has received little attention. Over the last decade three major reports from UN agencies have focused on the situation of children and youth with disabilities; the 2011 WHO/World Bank World Report on Disability (World Health Organization and World Bank, 2011), UNICEF's 2013 State of the World's Children report (UNICEF, 2013) and, most recently, the UN 'flagship' 2018 Disability and Development report (United Nations Department of Economic and Social Affairs, 2019). None mentioned the extent to which children with disabilities may be at risk of involvement in child labour. The scientific literature on this issue is equally silent. We are aware of only one published scientific study that has investigated this association; reporting that children with disabilities in Mexico were significantly more likely to engage in child labour overall (19.4\% vs. $12.5 \%)$ and hazardous child labour (13.0\% vs. $7.9 \%$ ) than their non-disabled peers (Villalobos et al., 2017). This omission is somewhat surprising given that children with disabilities are more likely to be exposed to a number of risk factors for engaging in child labour such as male gender, not being in education, living in low-income countries and living in poverty (Cappa et al., 2018; Emerson, Savage, \& Llewellyn, 2018; Filmer, 2008; Male \& Wodon, 2017; Spencer, Blackburn, \& Read, 2015).

The aims of the present paper were: (1) to estimate the strength of association between child disability and child labour in a range of middle- and low-income countries; and (2) to determine the extent to which any associations varied across different functional difficulties associated with disability.

\section{Method}

We undertook secondary analysis of nationally representative data collected in Round 6 (2017-) of UNICEF's Multiple Indicator Cluster Surveys (MICS: UNICEF, 2015). Following 
approval by UNICEF, MICS data were downloaded from http://mics.unicef.org/. At the end of the download period (1 May, 2020), data from 15 nationally representative surveys were available for three upper middle-income, seven lower middle-income and five low-income countries which contained data on child disability and child labour. All WHO Regions were represented in the data; Africa (8 countries), Europe (2 countries), Western Pacific ( 2 countries), South East Asia (1 country), the Americas (1 country) and Eastern Mediterranean (1 country).

MICS contains several questionnaire modules. Data used in the present paper were extracted from the household module and the module applied to a randomly selected child age 5-17 living in the household (Khan \& Hancioglu, 2019). The median overall response rate for the age 5-17 module was $96.3 \%$ (range $60.5 \%-99.9 \%)$. All countries used cluster sampling methods to derive samples representative of the national population of mothers and children. Specific details of the sampling procedure used in each country are available at

\section{http://mics.unicef.org/.}

\section{Disability}

In Round 6 of MICS a new module was introduced to identify children with disability aged 517. Developed by the Washington Group on Disability Statistics (WGDS:

http://www.washingtongroup-disability.com/), the module is based on informant report of child difficulties in 14 functional domains (seeing, hearing, walking, self-care, being understood inside the household, being understood outside the household, learning, remembering, focusing, accepting change, making friends, anxiety, depression, controlling behaviour). Four response options were available for all domains other than the anxiety, depression and behaviour domain ('no difficulty', 'some difficulty', 'a lot of difficulty', 'cannot do at all'). The controlling behaviour domain had five response options ('not at all', 
'less', 'the same', 'more' or 'a lot more') as did the anxiety and depression domains ('daily', 'weekly', 'monthly', 'a few times a year', 'never').

Initial validation of the new module estimated that using the cut-off recommended by the WGDS (primarily based on the child having at least 'a lot of difficulty' in at least one domain) resulted in a prevalence of child disability among $5-17$ year old children ranged from $3.2 \%$ to 11.2\% (Cappa et al., 2018). We used the cut-off recommended by the WGDS to define child disability associated with difficulties in the 14 specific functional domains listed above. For all disability measures the reference group was children with no disability. Disability data were missing for $2.6 \%$ of participants.

\section{Child Labour}

We used the Unicef/MICS age-specific definitions of child labour to identify children engaging in child labour: age 5 to 11 years, at least 1 hour of economic activities or 21 hours of unpaid household services per week; age 12 to 14 years, at least 14 hours of economic activities or 21 hours of unpaid household services per week; age 15 to 17 years, at least 43 hours of economic activities, no threshold for number of hours of unpaid household services.

Child labour was coded as hazardous if any of the following conditions were met: (1) activities required 'carrying heavy loads' or 'working with dangerous tools such as knives and similar or operating heavy machinery'; $(2)$ in the work environment the child is exposed to 'dust, fumes or gas', 'extreme cold, heat or humidity', 'loud noise or vibration' or 'to other things, processes or conditions bad for (his/her) health or safety'; (3) the child is 'required to work at heights' or 'with chemicals, such as pesticides, glues and similar, or explosives'. Child labour data were missing for $2.4 \%$ of participants. 


\section{Country Characteristics}

Given the commonly reported association between child wellbeing and national wealth in low and middle income countries (World Health Organization, 2008), we used World Bank 2018 country classification as upper middle income, lower middle income and low income (World Bank, 2017c). These classifications are based on per capita Gross National Income adjusted for purchasing power parity (pcGNI; expressed as current US\$ rates) using the World Bank's Atlas Method. We also downloaded 2018 Atlas Method pcGNI from the World Bank website in May 2020 (World Bank, 2017a, 2017b). We extracted Human Development Index (HDI) scores for each country from Human Development Report 2019 (United Nations Development Programme, 2019). The composite HDI integrates three dimensions of human development: life expectancy at birth; mean years of schooling and expected years of schooling; and gross national income per capita (Anand \& Sen, 1994).

\section{Household Wealth}

MICS data includes a within-country wealth index for each household. To construct the wealth index, principal components analysis is performed by using information on the ownership of consumer goods, dwelling characteristics, water and sanitation, and other characteristics that are related to the household's wealth, to generate weights for each item. Each household is assigned a wealth score based on the assets owned by that household weighted by factors scores. The wealth index is assumed to capture underlying long-term wealth through information on the household assets (Rutstein, 2008; Rutstein \& Johnson, 2004). Data were missing for $2.3 \%$ of children. 


\section{Maternal Education}

The highest level of education received by the child's mother was recorded using countryspecific categories. We recoded these data into a three-category measure: (1) no education;

(2) primary education; (3) receipt of secondary or higher-level education. Data were missing for $1.8 \%$ of children.

\section{Urban/Rural Location}

Data were released with a within-country defined binary indicator of urban/rural location for each household. No data were missing.

\section{Approach to Analysis}

In the first stage of analysis, we used simple bivariate descriptive statistics to estimate the prevalence of exposure to child labour (with 95\% confidence intervals) for each country and a pooled estimate overall. In the second stage of analysis, we used Poisson regression to estimate the within country adjusted relative risk ratio (ARRR) of children with disability being engaged in child labour. ARRRs were adjusted for child age and gender, maternal education, household wealth and urban/rural location. Multilevel modelling was used to estimate a pooled ARRR. Given the non-linear association between child age and the outcomes of interest, child age was treated as a categorical variable in all analyses.

In the third stage of analysis we correlated country-level prevalence of child labour and ARRRs for children with disability being engaged in child labour with two country characteristics; per capita GNI and HDI score. In the final stage of analysis, we used multilevel modelling to investigate the extent to which engagement in hazardous child 
labour varied by type of functional difficulty associated with disability and type of work hazard.

Prevalence analyses were undertaken using IBM SPSS v24 using the complex samples facility to take account of the clustering of observations by country and within country sampling clusters. Multilevel modelling of within-country associations was undertaken in Stata 12 using the xtmepoisson command to generate adjusted prevalence rate ratios (adjusted relative risk). UNICEF's country-specific child-level weights were used to take account of biases in sampling frames and household and individual level non-response. For pooled analyses we recalibrated the country specific weights to take account of between country differences in the child sampling fraction based on UNICEF's 2015 estimates of the population of children under the age of 5-18 years. Most missing data were clustered in a small group of children. If children with missing age data were excluded the level of missing data was reduced to less than $1.0 \%$ for all variables. As a result, complete case analyses were undertaken.

\section{Ethical Approval}

Ethical approval for each survey was provided by the relevant research ethics approval process in each participating country (see published country reports for full details at https://mics.unicef.org/surveys). Given the data provided by UNICEF had been stripped of all identifying information ethical approval specific to the analyses undertaken in the present paper was deemed unnecessary. 


\section{Results}

\section{Prevalence of disability}

The estimated prevalence of disability across the 15 countries was $15.7 \%$ (95\% Cl 14.4\%17.2\%). It ranged from 7.6\% (4.6\%-12.3\%) in Montenegro to $24.2 \%(21.3 \%-27.6 \%)$ in Sierra Leone. The association between disability status and demographic and living circumstance covariates is presented in Table 1.

\section{Prevalence of exposure to child labour among children with/without disabilities}

Pooled estimates across all 15 countries show higher prevalence rates among children with disabilities when compared to their non-disabled peers for child labour overall (17.8\% vs. $15.9 \%)$ and for hazardous child labour (9.9\% vs. $7.0 \%$ ) (Table 2$)$. When adjusted for child gender and age, the relative risk of children with disabilities engaging in child labour was $4 \%$ higher than for children without disabilities (ARRR=1.04 (1.00-1.08)), and 18\% higher for engaging in hazardous child labour (ARRR=1.18 (1.13-1.24)). Further adjusting for differences in household wealth, maternal education and urban/rural location reduced the magnitude of the increased risk to $1 \%$ for child labour (ARRR $=1.01(0.98-1.05))$ and $14 \%$ for hazardous child labour (ARRR=1.15 (1.10-1.21)).

The overall prevalence of child labour and hazardous child labour increased as per capita GNI decreased (child labour Spearman's $r=-0.61, p<0.05$; hazardous child labour $r=-0.78$, $p<0.01$ ) and country HDI score decreased (child labour $r=-0.47$, n.s.; hazardous child labour $r=-0.72, p<0.01)$. However, adjusted relative risk of exposure among children with disabilities was unrelated to either per capita GNI or country HDI score (all $r<0.2$ ). 


\section{Exposure to specific hazards}

The types of specific hazards to which children engaging in hazardous child labour were exposed are presented in Table 3. Children with disabilities were significantly more likely than their non-disabled peers to engage in all forms of hazardous child labour with one exception; labour that involved working with dangerous tools or heavy machinery. They were at highest risk for work that exposed them to loud noise or vibration or required them to work at heights.

\section{Association with type of functional impairment}

Exposure to hazardous child labour was significantly higher for children who had severe difficulties in the functional domains of learning/remembering and controlling their behaviour (Table 4). In contrast, it was significantly lower for children who had severe functional difficulties in walking, self-care and being understood by others. These patterns of association were broadly consistent across all specific work-related hazards.

\section{Discussion}

Pooled estimates across all 15 countries indicated that: (1) children and youth with disabilities were $4 \%$ more likely than other children to engage in child labour and $18 \%$ more likely to engage in hazardous child labour; (2) the adjusted relative risk of exposure among children and youth with disabilities was unrelated to either per capita GNI or country HDI score; (3) children and youth with disabilities were at highest risk for exposure to work that involved loud noise or vibration or required them to work at heights; (4) exposure to hazardous child labour was significantly higher for children and youth who had severe functional difficulties in learning/remembering, controlling their behaviour and mental 
health problems. In contrast, it was significantly lower for children and youth who had severe functional difficulties in walking, self-care and being understood by others. These patterns of association were broadly consistent across all specific work-related hazards.

Our results add to the existing literature in two important ways. First, this is the first study to report estimates of the extent to which children and youth with disabilities are likely to engage in child labour when compared with their non-disabled peers across a range of middle- and low-income countries. The ILO estimated that on any given day in 2016, 73 million children were engaged in hazardous work (International Labour Organization, 2017). Given our estimated prevalence of child disability of $15.7 \%$ and an $18 \%$ increase in probability of engaging in hazardous child labour, it is likely that 13.5 million of these children were children with disabilities.

Interventions aimed at reducing inequities need to take account of the specific situations faced by marginalised groups who are at increased risk of being treated inequitably (Carey, Crammond, \& De Leeuw, 2015; Marmot et al., 2012). In the context of child labour, along with many other examples of social inequities facing children and youth such as exposure to violence (Jones et al., 2012), children with disabilities form one such group. For example, UNICEF has argued that increasing school enrolment and reducing school drop-out could have a significant impact on the prevalence of reducing hazardous child labour (UNICEF, 2014). Such initiatives, however, would need to specifically address both the low school enrolment rates of children with disabilities in middle- and low-income countries (Filmer, 2008; Male \& Wodon, 2017) as well as the increased risk of exposure of children with disabilities to peer violence in school settings (e.g., King et al., 2018). 
Second, our results also highlight the important role that specific functional impairments/difficulties associated with child disability may play in increasing the risk of exposure to hazardous child labour and specific forms of hazardous child labour. Specifically, exposure to hazardous child labour was significantly higher for children who had severe functional limitations in learning/remembering, controlling their behaviour and evidence of mental health problems and increased rates of exposure were evident for several different forms of hazardous child labour. These impairments are associated in high income countries with higher rates of exposure to household poverty and violence (Emerson, Graham, \& Hatton, 2006; Emerson \& Roulstone, 2014) and are likely to be related to lower rates of school enrolment and higher rates of school drop-out in middle- and low income countries (Wodon, Male, Montenegro, \& Nayihouba, 2018).

Our results need to be considered in the context of two major limitations of our study. First, all our data are cross-sectional. As a result, we cannot draw any conclusions about the nature of causal pathways linking child disability to hazardous child labour. We consider it likely, however, that three separate pathways are involved. First, the structural and interpersonal discrimination faced by children with disabilities (e.g., their exclusion from education) are likely to increase the risk that they will engage in hazardous child labour. Second, the association between child disability and male gender and household poverty (two well established risk factors for engaging in hazardous child labour) suggests that they are already at greater risk due to their gender and family context. It is important to note, however, that the associations we describe are still evident when appropriate statistical controls are made for these between-group differences. Third, engagement in hazardous child labour may lead to an increased risk of acquiring a disability (Dalal et al., 2015; 
Forastieri, 1997; Ibrahim et al., 2019; Kuimi et al., 2018; Shendell et al., 2016; Sturrock \& Hodes, 2016). It is not possible, at present, to compare the relative importance of these three general pathways.

The second major limitation of our study is that there may be some systematic biases in the identification of child disability. The WGDS questions ask the informant to make a general judgement about their child's progress relative to 'children of the same age'. The use of such a strategy in surveys which are designed to generate robust national level data is based on the assumptions that: (1) parental informants have sufficient knowledge of the abilities of 'children of the same age' in their homeland; and (2) there will be no systematic biases in errors made by parental informants as a result of such factors as urban/rural location, household wealth/poverty, or informant level of education. It appears that in some domains (e.g., learning difficulties) such biases do exist leading to possible over-identification in wealthier/more educated families and under-identification in poorer/less educated families (Redacted to preserve anonymity of authors, 2020).

Future research is required to determine whether our results generalize to other middleand low-income countries and over time. The latter may be particularly important given that concern has been expressed that the 2020 COVID-19 pandemic may lead to significant increases in the prevalence of child labour (International Labour Organization \& UNICEF, 2020).

\section{References}

Anand, S., \& Sen, A. K. (1994). Human Development Index: Methodology and Measurement New York: United Nations Development Programme. 
Bourdillon, M., \& Carothers, R. (2019). Policy on Children's Work and Labour. Children \& Society, 33(4), 387-395. doi:10.1111/chso.12313

Cappa, C., Mont, D., Loeb, M., Misunas, C., Madans, J., Comic, T., \& De Castro, F. (2018). The Development and Testing of a Module on Child Functioning for Identifying Children with Disabilities on Surveys. III: Field Testing. Disability and Health Journal, 11(4), 510-518.

Carey, G., Crammond, B., \& De Leeuw, E. (2015). Towards health equity: a framework for the application of proportionate universalism. International Journal for Equity in Health, 14, 81.

Dalal, K., Rahman, F., Gifford, M., \& Rahman, A. (2015). The magnitude of injury problems among child labourers in a rural community of Bangladesh: findings from an injury surveillance system. International Health, 8, 73-76.

Emerson, E., Graham, H., \& Hatton, C. (2006). Household income and health status in children and adolescents: cross sectional study. European Journal of Public Health, 16, 354-360.

Emerson, E., \& Roulstone, A. (2014). Developing an evidence base for violent and disablist hate crime in the Britain: Findings from the Life Opportunities Survey. Journal of Interpersonal Violence, 29, 3086-3104 doi:10.1177/0886260514534524

Emerson, E., Savage, A., \& Llewellyn, G. (2018). Significant cognitive delay among 3- to 4-year old children in low- and middle-income countries: prevalence estimates and potential impact of preventative interventions. International Journal of Epidemiology, 47, 1465-1474. doi:10.1093/ije/dyy161

Filmer, D. (2008). Disability, Poverty, and Schooling in Developing Countries: Results from 14 Household Surveys. World Bank Economic Review, 22, 141-163.

Forastieri, V. (1997). Children at Work: Health and safety risks. Retrieved from Geneva:

Ibrahim, A., Abdalla, S. M., Jafer, M., Abdelgadir, J., \& de Vries, N. (2019). Child labor and health: a systematic literature review of the impacts of child labor on child's health in low- and middle-income countries. Journal of Public Health, 41(1), 18-26. doi:10.1093/pubmed/fdy018 
International Labour Organization. (2017). Global Estimates of Child Labour: Results and Trends 2012-2016. Geneva: International Labour Office.

International Labour Organization. (2018). Toward the Urgent Elimination of Hazardous Child Labour. Retrieved from Geneva:

International Labour Organization, \& UNICEF. (2020). COVID-19 And Child Labour: A Time Of Crisis, A Time To Act. Retrieved from Geneva:

Jones, L., Bellis, M. A., Wood, S., Hughes, K., McCoy, E., Eckley, L., . . Officer, A. (2012). Prevalence and risk of violence against children with disabilities: a systematic review and meta-analysis of observational studies. Lancet, 380(9845), 899-907.

Khan, S., \& Hancioglu, A. (2019). Multiple Indicator Cluster Surveys: Delivering Robust Data on Children andWomen across the Globe. Studies in Family Planning, 50, 279-286.

Khatab, K., Raheem, M. A., Sartorius, B., \& Ismail, M. (2019). Prevalence and risk factors for child labour and violence against children in Egypt using Bayesian geospatial modelling with multiple imputation. PLOS ONE, 14(5). doi:10.1371/journal.pone.0212715

King, T., Aitken, Z., Milner, A., Emerson, E., Priest, N., Karahalios, E., . . Blakely, A. (2018). To what extent is the association between disability and mental health in adolescents mediated by bullying? A causal mediation analysis. International Journal of Epidemiology, 47, 1402-1413.

Kuimi, B. L. B., Oppong-Nkrumah, O., Kaufman, J., Nazif-Munoz, J. I., \& Nandi, A. (2018). Child labour and health: a systematic review. International Journal of Public Health, 63(5), 663-672. doi:10.1007/s00038-018-1075-9

Male, C., \& Wodon, Q. (2017). Disability Gaps in Educational Attainment and Literacy. Washington, DC: World Bank.

Marmot, M., Allen, J., Bell, R., Bloomer, E., Goldblatt, P., \& on behalf of the Consortium for the European Review of Social Determinants of Health and the Health Divide. (2012). WHO European review of social determinants of health and the health divide. Lancet, 380, 10111029. 
Posso, A. (2019). The health consequences of hazardous and nonhazardous child labor. Review of Development Economics, 23(2), 619-639. doi:10.1111/rode.12571

Redacted to preserve anonymity of authors. (2020).

Rutstein, S. O. (2008). The DHS Wealth Index: Approaches for Rural and Urban Areas. DHS Working Papers No. 60. Retrieved from Calverton, Maryland:

Rutstein, S. O., \& Johnson, K. (2004). The DHS Wealth Index: DHS Comparative Reports No. 6. Retrieved from Calverton, Maryland:

Shendell, D. G., Noomnual, S., Chishti, S., Allacci, M. A., \& Madrigano, J. (2016). Exposures Resulting in Safety and Health Concerns for Child Laborers in Less Developed Countries. Journal of Environmenal and Public Health, 3985498. doi:10.1155/2016/3985498

Spencer, N., Blackburn, C., \& Read, J. (2015). Disabling Chronic Conditions in Childhood and socioeconomic disadvantage: a systematic review and meta-analyses of observational studies. BMJ Open, 5, e007062. doi:007010.001136/bmjopen-002014-007062.

Sturrock, S., \& Hodes, M. (2016). Child labour in low- and middle-income countries and its consequences for mental health: a systematic literature review of epidemiologic studies. European Child \& Adolescent Psychiatry, 25(12), 1273-1286. doi:10.1007/s00787-016-0864-z

UNICEF. (2013). The State of the World's Children 2013: Children withn Disabilities. Retrieved from New York:

UNICEF. (2014). Child Labour and UNICEF in Action: Children at the Centre. New York: UNICEF.

UNICEF. (2015). Monitoring the Situation of Children and Women for 20 Years: The Multiple Indicator Cluster Surveys (MICS) 1995-2015. Retrieved from New York:

United Nations Department of Economic and Social Affairs. (2019). Disability and Development Report: Realizing the Sustainable Development Goals by, for and with persons with disabilities Retrieved from New York: 
United Nations Development Programme. (2019). Human Development Report 2019. Beyond income, beyond averages, beyond today: Inequalities in human development in the 21st century. Retrieved from New York:

Villalobos, A., de Castro, F., Rojas, R., Allen-Leigh, B., Hubert, C., Avendano-Badillo, D., . . LazcanoPonce, E. (2017). Child labor and severe functioning difficulties and disability in Mexican children and adolescents 5-17 years of age. Salud Publica De Mexico, 59(4), 380-388. doi:10.21149/8483

Wodon, Q., Male, C., Montenegro, C., \& Nayihouba, A. (2018). The Challenge of Inclusive Education in Sub-Saharan Africa. Washington, DC: World Bank.

World Bank. (2017a). GNI per capita, Atlas method (current US\$). <http://data.worldbank.org/indicator/NY.GNP.PCAP.CD?view=chart> accessed 08/19/2017. World Bank. (2017b). The World Bank Atlas method - detailed methodology. <https://datahelpdesk.worldbank.org/knowledgebase/articles/378832-what-is-the-worldbank-atlas-method> accessed 08/19/2017.

World Bank. (2017c). World Bank Country and Lending Groups. <https://datahelpdesk.worldbank.org/knowledgebase/articles/906519-world-bank-countryand-lending-groups > accessed 08/19/2017.

World Health Organization. (2008). Closing the gap in a generation: Health equity through action on the social determinants of health. Final report of the Commission on the Social Determinants of Health. Geneva: World Health Organization.

World Health Organization and World Bank. (2011). World report on disability. Retrieved from Malta: 


\begin{tabular}{|c|c|c|c|c|c|}
\hline & \multicolumn{2}{|c|}{ Disability } & \multicolumn{2}{|c|}{ No disability } & \multirow[b]{2}{*}{ Chi-Sq } \\
\hline & $\mathrm{N}$ & $\%$ & $\mathrm{n}$ & $\%$ & \\
\hline \multicolumn{6}{|l|}{ Gender } \\
\hline Boys & 11,996 & $52.5 \%$ & 61,469 & $50.2 \%$ & \multirow[t]{2}{*}{$38.8(1), p<0.001$} \\
\hline Girls & 10,868 & $47.5 \%$ & 60,920 & $49.8 \%$ & \\
\hline \multicolumn{6}{|l|}{ Age } \\
\hline 5 & 2,325 & $10.2 \%$ & 10,768 & $8.8 \%$ & \multirow[t]{13}{*}{$340.6(12), p<0.001$} \\
\hline 6 & 2,258 & $9.9 \%$ & 10,316 & $8.4 \%$ & \\
\hline 7 & 2,182 & $9.5 \%$ & 9,914 & $8.1 \%$ & \\
\hline 8 & 1,915 & $8.4 \%$ & 10,270 & $8.4 \%$ & \\
\hline 9 & 1,970 & $8.6 \%$ & 9,079 & $7.4 \%$ & \\
\hline 10 & 1,741 & $7.6 \%$ & 9,943 & $8.1 \%$ & \\
\hline 11 & 1,778 & $7.8 \%$ & 9,377 & $7.7 \%$ & \\
\hline 12 & 1,755 & $7.7 \%$ & 9,821 & $8.0 \%$ & \\
\hline 13 & 1,668 & $7.3 \%$ & 9,025 & $7.4 \%$ & \\
\hline 14 & 1,489 & $6.5 \%$ & 8,985 & $7.3 \%$ & \\
\hline 15 & 1,381 & $6.0 \%$ & 9,034 & $7.4 \%$ & \\
\hline 16 & 1,209 & $5.3 \%$ & 7,853 & $6.4 \%$ & \\
\hline 17 & 1,192 & $5.2 \%$ & 8,005 & $6.5 \%$ & \\
\hline \multicolumn{6}{|l|}{$\begin{array}{l}\text { Household wealth } \\
\text { index quintile }\end{array}$} \\
\hline 1 (poorest) & 5,546 & $24.3 \%$ & 25,801 & $21.1 \%$ & \multirow[t]{5}{*}{$234.6(4), p<0.001$} \\
\hline 2 & 5,094 & $22.3 \%$ & 25,950 & $21.2 \%$ & \\
\hline 3 & 4,674 & $20.4 \%$ & 24,979 & $20.4 \%$ & \\
\hline 4 & 4,181 & $18.3 \%$ & 23,464 & $19.2 \%$ & \\
\hline 5 (richest) & 3,370 & $14.7 \%$ & 22,195 & $18.1 \%$ & \\
\hline \multicolumn{6}{|l|}{$\begin{array}{l}\text { Highest level of } \\
\text { maternal education }\end{array}$} \\
\hline None & 6,254 & $27.4 \%$ & 32,679 & $26.8 \%$ & \multirow[t]{3}{*}{$61.2(2), p<0.001$} \\
\hline Primary & 7,609 & $33.4 \%$ & 38,297 & 31.4 & \\
\hline Secondary or higher & 8,931 & $39.2 \%$ & 51,113 & $41.9 \%$ & \\
\hline \multicolumn{6}{|l|}{ Location } \\
\hline Urban & 8,630 & $37.7 \%$ & 42,691 & $34.9 \%$ & \multirow[t]{2}{*}{$69.1(1), p<0.001$} \\
\hline Rural & 14,234 & $62.3 \%$ & 79,698 & $65.1 \%$ & \\
\hline
\end{tabular}




\begin{tabular}{|c|c|c|c|c|c|c|c|c|c|c|c|c|}
\hline \multirow[t]{2}{*}{ Country/Group } & \multirow{2}{*}{$\begin{array}{l}\text { Sample } \\
\text { size }\end{array}$} & \multirow{2}{*}{$\begin{array}{l}\text { Year of } \\
\text { Survey }\end{array}$} & \multirow{2}{*}{$\begin{array}{l}\text { pcGNI } \\
(2018)\end{array}$} & \multirow{2}{*}{$\begin{array}{c}\text { Country } \\
\text { HDI } \\
\text { Score } \\
(2018)\end{array}$} & \multicolumn{4}{|c|}{ Child Labour } & \multicolumn{4}{|c|}{ Hazardous Child Labour } \\
\hline & & & & & Disability & $\begin{array}{l}\text { No } \\
\text { Disability }\end{array}$ & Overall & ARR & Disability & $\begin{array}{l}\text { No } \\
\text { Disability }\end{array}$ & Overall & ARR \\
\hline \multicolumn{13}{|c|}{ Upper Middle-Income Countries } \\
\hline Montenegro & 1,156 & $2018 / 19$ & $\$ 8,430$ & 0.816 & $\begin{array}{r}1.8 \% \\
(0.5-5.7)\end{array}$ & $\begin{array}{r}8.3 \% \\
(5.9-11.6)\end{array}$ & $\begin{array}{r}7.8 \% \\
(5.6-10.9)\end{array}$ & $\begin{array}{r}0.25 \\
(0.08-0.84)\end{array}$ & $\begin{array}{r}0.0 \% \\
(0.0-3.6)\end{array}$ & $\begin{array}{r}0.6 \% \\
(0.2-1.4)\end{array}$ & $\begin{array}{r}0.5 \% \\
(0.2-1.3)\end{array}$ & $\begin{array}{r}0.00^{* *} \\
(0.00-0.01)\end{array}$ \\
\hline Suriname & 3,966 & 2018 & $\$ 5,210$ & 0.724 & $\begin{array}{r}5.8 \% \\
(4.2-8.0) \\
\end{array}$ & $\begin{array}{r}4.1 \% \\
(3.5-4.8) \\
\end{array}$ & $\begin{array}{r}4.4 \% \\
(3.8-5.1) \\
\end{array}$ & $\begin{array}{r}1.07 \\
(0.78-2.28) \\
\end{array}$ & $\begin{array}{r}2.4 \% \\
(1.4-4.0) \\
\end{array}$ & $\begin{array}{r}0.4 \% \\
(0.2-0.7) \\
\end{array}$ & $\begin{array}{r}0.7 \% \\
(0.5-1.0) \\
\end{array}$ & $\begin{array}{r}4.34^{*} \\
(1.75-10.74) \\
\end{array}$ \\
\hline Iraq & 15,592 & 2018 & $\$ 5,040$ & 0.689 & $\begin{array}{r}4.7 \% \\
(3.7-6.1)\end{array}$ & $\begin{array}{r}4.4 \% \\
(3.7-5.3) \\
\end{array}$ & $\begin{array}{r}4.5 \% \\
(3.8-5.2) \\
\end{array}$ & $\begin{array}{r}1.06 \\
(0.70-1.42) \\
\end{array}$ & $\begin{array}{r}2.8 \% \\
(2.1-3.7) \\
\end{array}$ & $\begin{array}{r}2.2 \% \\
(1.7-2.8) \\
\end{array}$ & $\begin{array}{r}2.3 \% \\
(1.9-2.8) \\
\end{array}$ & $\begin{array}{r}1.13 \\
(0.82-1.55) \\
\end{array}$ \\
\hline \multicolumn{13}{|c|}{ Lower Middle-Income Countries } \\
\hline Mongolia & 7,443 & 2018 & $\$ 3,660$ & 0.735 & $\begin{array}{r}17.5 \% \\
(13.3-22.6)\end{array}$ & $\begin{array}{r}14.6 \% \\
(13.1-16.2)\end{array}$ & $\begin{array}{r}14.8 \% \\
(13.3-16.4)\end{array}$ & $\begin{array}{r}1.13 \\
(0.85-1.50)\end{array}$ & $\begin{array}{r}5.0 \% \\
(3.0-8.1) \\
\end{array}$ & $\begin{array}{r}4.2 \% \\
(3.4-5.1)\end{array}$ & $\begin{array}{r}4.2 \% \\
(3.5-5.2) \\
\end{array}$ & $\begin{array}{r}1.07 \\
(0.65-1.78)\end{array}$ \\
\hline Kiribati & 2,261 & 2018/19 & $\$ 3,140$ & 0.623 & $\begin{array}{r}12.5 \% \\
(9.1-17.0)\end{array}$ & $\begin{array}{r}17.8 \% \\
(15.4-20.4)\end{array}$ & $\begin{array}{r}16.6 \% \\
(14.6-18.8)\end{array}$ & $\begin{array}{r}0.72 \\
(0.54-0.96)\end{array}$ & $\begin{array}{r}4.5 \% \\
(2.8-7.1)\end{array}$ & $\begin{array}{r}5.1 \% \\
(3.9-6.6)\end{array}$ & $\begin{array}{r}4.9 \% \\
(3.9-6.3)\end{array}$ & $\begin{array}{r}0.88 \\
(0.54-1.44)\end{array}$ \\
\hline Ghana & 8,941 & $2017 / 18$ & $\$ 2,130$ & 0.596 & $\begin{array}{r}21.1 \% \\
(18.1-24.4)\end{array}$ & $\begin{array}{r}19.8 \% \\
(18.2-21.6)\end{array}$ & $\begin{array}{r}20.1 \% \\
(18.7-21.6)\end{array}$ & $\begin{array}{r}1.02 \\
(0.88-1.18)\end{array}$ & $\begin{array}{r}13.7 \% \\
(11.0-16.9)\end{array}$ & $\begin{array}{r}8.8 \% \\
(7.6-10.0)\end{array}$ & $\begin{array}{r}9.8 \% \\
(8.6-11.2)\end{array}$ & $\begin{array}{r}1.47^{* *} \\
(1.19-1.82)\end{array}$ \\
\hline Zimbabwe & 7,033 & $2018 / 19$ & $\$ 1,790$ & 0.563 & $\begin{array}{r}33.8 \% \\
(29.3-38.6) \\
\end{array}$ & $\begin{array}{r}27.2 \% \\
(25.3-29.1) \\
\end{array}$ & $\begin{array}{r}27.9 \% \\
(26.2-29.7) \\
\end{array}$ & $\begin{array}{r}1.14 \\
(1.01-1.28) \\
\end{array}$ & $\begin{array}{r}7.6 \% \\
(5.6-10.1)\end{array}$ & $\begin{array}{r}6.0 \% \\
(5.1-7.0) \\
\end{array}$ & $\begin{array}{r}6.1 \% \\
(5.3-7.1) \\
\end{array}$ & $\begin{array}{r}1.11 \\
(0.80-1.53) \\
\end{array}$ \\
\hline Bangladesh & 39,504 & 2019 & $\$ 1,750$ & 0.614 & $\begin{array}{r}8.3 \% \\
(7.2-9.6)\end{array}$ & $\begin{array}{r}6.6 \% \\
(6.3-7.0)\end{array}$ & $\begin{array}{r}6.8 \% \\
(6.4-7.1)\end{array}$ & $\begin{array}{r}1.18 \\
(1.02-1.37)\end{array}$ & $\begin{array}{r}4.6 \% \\
(3.8-5.6)\end{array}$ & $\begin{array}{r}3.4 \% \\
(3.1-3.6)\end{array}$ & $\begin{array}{r}3.5 \% \\
(3.2-3.7)\end{array}$ & $\begin{array}{r}1.30 * \\
(1.06-1.58)\end{array}$ \\
\hline Lesotho & 4,998 & 2018 & $\$ 1,390$ & 0.518 & $\begin{array}{r}12.5 \% \\
(9.1-16.9) \\
\end{array}$ & $\begin{array}{r}14.1 \% \\
(12.6-15.7) \\
\end{array}$ & $\begin{array}{r}13.9 \% \\
(12.5-15.5) \\
\end{array}$ & $\begin{array}{r}0.92 \\
(0.68-1.24) \\
\end{array}$ & $\begin{array}{r}3.0 \% \\
(1.8-5.0) \\
\end{array}$ & $\begin{array}{r}4.4 \% \\
(3.6-5.3) \\
\end{array}$ & $\begin{array}{r}4.3 \% \\
(3.6-5.1) \\
\end{array}$ & $\begin{array}{r}0.73 \\
(0.42-1.27) \\
\end{array}$ \\
\hline Kyrgyz Republic & 3,890 & 2018 & $\$ 1,220$ & 0.674 & $\begin{array}{r}27.3 \% \\
(23.0-32.1) \\
\end{array}$ & $\begin{array}{r}21.8 \% \\
(20.5-23.2) \\
\end{array}$ & $\begin{array}{r}22.3 \% \\
(21.0-23.6) \\
\end{array}$ & $\begin{array}{r}1.13 \\
(0.88-1.46) \\
\end{array}$ & $\begin{array}{r}7.9 \% \\
(5.5-11.1) \\
\end{array}$ & $\begin{array}{r}5.2 \% \\
(4.5-6.0) \\
\end{array}$ & $\begin{array}{r}5.4 \% \\
(4.7-6.2) \\
\end{array}$ & $\begin{array}{r}1.38 \\
(0.82-2.31) \\
\end{array}$ \\
\hline \multicolumn{13}{|c|}{ Low-Income Countries } \\
\hline The Gambia & 5,711 & 2018 & $\$ 710$ & 0.466 & $\begin{array}{r}16.1 \% \\
(12.1-21.0)\end{array}$ & $\begin{array}{r}17.0 \% \\
(15.2-19.0)\end{array}$ & $\begin{array}{r}16.6 \% \\
(15.2-18.8)\end{array}$ & $\begin{array}{r}0.94 \\
(0.72-1.22)\end{array}$ & $\begin{array}{r}6.8 \% \\
(4.5-10.0)\end{array}$ & $\begin{array}{r}6.9 \% \\
(5.7-8.3)\end{array}$ & $\begin{array}{r}6.9 \% \\
(5.7-8.2)\end{array}$ & $\begin{array}{r}0.96 \\
(0.63-1.45)\end{array}$ \\
\hline Togo & 4,969 & 2017 & $\$ 660$ & 0.513 & $\begin{array}{r}41.2 \% \\
(36.6-46.0)\end{array}$ & $\begin{array}{r}37.8 \% \\
(35.1-40.6)\end{array}$ & $\begin{array}{r}38.6 \% \\
(36.0-41.2)\end{array}$ & $\begin{array}{r}1.14 \\
(1.03-1.27)\end{array}$ & $\begin{array}{r}30.0 \% \\
(25.8-34.5)\end{array}$ & $\begin{array}{r}20.7 \% \\
(18.0-23.7)\end{array}$ & $\begin{array}{r}22.8 \% \\
(20.2-25.6)\end{array}$ & $\begin{array}{r}1.52^{* * *} \\
(1.31-1.75)\end{array}$ \\
\hline
\end{tabular}




\begin{tabular}{|c|c|c|c|c|c|c|c|c|c|c|c|c|}
\hline Madagascar & 11,978 & 2018 & $\$ 510$ & 0.521 & $\begin{array}{r}36.1 \% \\
(32.8-39.5) \\
\end{array}$ & $\begin{array}{r}36.8 \% \\
(35.3-38.4) \\
\end{array}$ & $\begin{array}{r}36.7 \% \\
(35.3-38.2) \\
\end{array}$ & $\begin{array}{r}1.01 \\
(0.93-1.10) \\
\end{array}$ & $\begin{array}{r}20.7 \% \\
(18.1-23.5) \\
\end{array}$ & $\begin{array}{r}20.5 \% \\
(19.2-21.8) \\
\end{array}$ & $\begin{array}{r}20.5 \% \\
(19.3-21.8) \\
\end{array}$ & $\begin{array}{r}1.06 \\
(0.94-1.20) \\
\end{array}$ \\
\hline DR Congo & 14,027 & $2017 / 18$ & $\$ 490$ & 0.459 & $\begin{array}{r}15.1 \% \\
(12.8-17.7)\end{array}$ & $\begin{array}{r}14.6 \% \\
(12.8-16.7)\end{array}$ & $\begin{array}{r}14.7 \% \\
(13.2-16.4)\end{array}$ & $\begin{array}{r}0.99 \\
(0.84-1.16)\end{array}$ & $\begin{array}{r}5.7 \% \\
(4.5-7.3)\end{array}$ & $\begin{array}{r}5.4 \% \\
(4.4-6.5)\end{array}$ & $\begin{array}{r}5.4 \% \\
(4.6-6.4)\end{array}$ & $\begin{array}{r}1.04 \\
(0.80-1.36)\end{array}$ \\
\hline Sierra Leone & 11,030 & 2017 & $\$ 490$ & 0.438 & $\begin{array}{r}23.5 \% \\
(21.9-25.2) \\
\end{array}$ & $\begin{array}{r}25.8 \% \\
(24.9-26.8) \\
\end{array}$ & $\begin{array}{r}25.3 \% \\
(24.5-26.1) \\
\end{array}$ & $\begin{array}{r}0.86^{*} \\
(0.79-0.94) \\
\end{array}$ & $\begin{array}{r}16.6 \% \\
(15.2-18.1) \\
\end{array}$ & $\begin{array}{r}15.9 \% \\
(15.1-16.7) \\
\end{array}$ & $\begin{array}{r}16.1 \% \\
(15.4-16.8) \\
\end{array}$ & $\begin{array}{r}0.97 \\
(0.87-1.09) \\
\end{array}$ \\
\hline \multicolumn{13}{|l|}{ All Countries } \\
\hline $\begin{array}{l}\text { Pooled } \\
\text { Estimate }\end{array}$ & 142,499 & & & & $\begin{array}{r}17.8 \% \\
(16.5-19.0) \\
\end{array}$ & $\begin{array}{r}15.9 \% \\
(14.9-16.9) \\
\end{array}$ & $\begin{array}{r}16.2 \% \\
(15.2-17.2) \\
\end{array}$ & $\begin{array}{r}1.01 \\
(0.98-1.05) \\
\end{array}$ & $\begin{array}{r}9.9 \% \\
(8.7-11.2) \\
\end{array}$ & $\begin{array}{r}7.0 \% \\
(6.4-7.8) \\
\end{array}$ & $\begin{array}{r}7.5 \% \\
(6.8-8.3) \\
\end{array}$ & $\begin{array}{r}1.15^{* *} \\
(1.10-1.21)\end{array}$ \\
\hline
\end{tabular}




\begin{tabular}{|r|l|l|l|}
\hline \multicolumn{4}{|l|}{ Table 3: Exposure rates to hazardous child labour associated with specific hazards } \\
\hline Type of Hazard & Disabilities & No disabilities & Adjusted relative risk \\
\hline Exposed to loud noise or vibration & $8.5 \%(6.9-10.4)$ & $6.8 \%(5.6-8.1)$ & $1.48^{* *}(1.30-1.68)$ \\
\hline Required to work at heights & $9.3 \%(7.2-11.9)$ & $6.1 \%(5.1-7.3)$ & $1.42^{* *}(1.27-1.58)$ \\
\hline Exposed to dust, fumes or gas & $25.8 \%(22.7-29.2)$ & $20.8 \%(18.9-22.8)$ & $1.24^{* *}(1.16-1.33)$ \\
\hline Carrying heavy loads & $30.2 \%(26.0-34.8)$ & $23.7 \%(21.7-25.8)$ & $1.21^{* *}(1.14-1.29)$ \\
\hline Exposed to extreme temperatures or humidity & $35.6 \%(31.5-39.9)$ & $27.9 \%(24.7-31.3)$ & $1.19^{* *}(1.12-1.25)$ \\
\hline Required to work with chemicals & $5.9 \%(4.4-7.8)$ & $4.0 \%(3.2-4.9)$ & $1.18(1.00-1.39)$ \\
\hline $\begin{array}{l}\text { Wote: Note: }{ }^{*} p<0.01, * * \\
\text { Models }\end{array}$ adjusted for child age and gender, household wealth, highest level of maternal education and urban/rural status \\
\hline
\end{tabular}




\begin{tabular}{|c|c|c|c|c|c|c|c|c|}
\hline $\begin{array}{l}\text { Type of severe } \\
\text { functional impairment }\end{array}$ & All & Noise & Heights & Temp & Chemicals & Loads & $\begin{array}{l}\text { Tools \& } \\
\text { Machinery }\end{array}$ & Fumes \\
\hline Learning & $\begin{array}{l}1.27^{* *} \\
(1.14-1.42)\end{array}$ & $\begin{array}{l}1.39 * \\
(1.10-1.77)\end{array}$ & $\begin{array}{l}1.35 \\
(1.07-1.71) \\
\end{array}$ & $\begin{array}{l}1.25^{* *} \\
(1.12-1.40)\end{array}$ & $\begin{array}{l}1.48^{*} \\
(1.14-1.93)\end{array}$ & $\begin{array}{l}1.27^{* *} \\
(1.13-1.44)\end{array}$ & $\begin{array}{l}1.27^{* *} \\
(1.12-1.44)\end{array}$ & \begin{tabular}{|l|}
1.18 \\
$(1.03-1.35)$ \\
\end{tabular} \\
\hline Remembering & $\begin{array}{l}1.24^{* *} \\
(1.10-1.39)\end{array}$ & $\begin{array}{l}1.20 \\
(0.91-1.57)\end{array}$ & \begin{tabular}{|l|}
0.97 \\
$(0.72-1.30)$ \\
\end{tabular} & $\begin{array}{l}1.16 \\
(1.03-1.30)\end{array}$ & $\begin{array}{l}1.51^{*} \\
(1.1 .16-1.98)\end{array}$ & $\begin{array}{l}1.33^{* *} \\
(1.18-1.51) \\
\end{array}$ & $\begin{array}{l}1.34^{* *} \\
(1.18-1.52) \\
\end{array}$ & \begin{tabular}{|l|}
$1.30^{* *}$ \\
$(1.14-1.49)$ \\
\end{tabular} \\
\hline Hearing & $\begin{array}{l}1.19 \\
(0.91-1.56)\end{array}$ & $\begin{array}{l}1.34 \\
(0.72-2.51)\end{array}$ & \begin{tabular}{|l|}
1.75 \\
$(1.07-2.87)$ \\
\end{tabular} & $\begin{array}{l}1.05 \\
(0.80-1.38)\end{array}$ & $\begin{array}{l}1.53 \\
(0.82-2.84)\end{array}$ & $\begin{array}{l}1.38 \\
(1.04-1.83)\end{array}$ & $\begin{array}{l}1.17 \\
(0.85-1.61)\end{array}$ & $\begin{array}{l}1.24 \\
(0.91-1.69) \\
\end{array}$ \\
\hline Controlling behaviour & $\begin{array}{l}1.18^{*} \\
(1.05-1.32)\end{array}$ & $\begin{array}{l}1.27 \\
(1.01-1.60)\end{array}$ & $\begin{array}{l}1.31 \\
(1.06-1.63)\end{array}$ & $\begin{array}{l}1.31 * * \\
(1.18-1.46)\end{array}$ & $\begin{array}{l}1.25 \\
(0.95-1.65)\end{array}$ & $\begin{array}{l}1.35^{* *} \\
(1.20-1.51)\end{array}$ & $\begin{array}{l}1.34^{* *} \\
(1.19-1.51)\end{array}$ & \begin{tabular}{|l|}
$1.24^{*}$ \\
$(1.10-1.41)$
\end{tabular} \\
\hline Dealing with change & $\begin{array}{l}1.14 \\
(1.02-1.27)\end{array}$ & $\begin{array}{l}1.40^{*} \\
(1.12-1.74)\end{array}$ & $\begin{array}{l}1.53^{* *} \\
(1.26-1.85) \\
\end{array}$ & $\begin{array}{l}1.33 * * \\
(1.21-1.47)\end{array}$ & $\begin{array}{l}1.16 \\
(0.89-1.50)\end{array}$ & $\begin{array}{l}1.36 * * \\
(1.22-1.52)\end{array}$ & $\begin{array}{l}1.04 \\
(0.92-1.18)\end{array}$ & \begin{tabular}{|l|}
1.15 \\
$(1.01-1.30)$ \\
\end{tabular} \\
\hline Anxiety & $\begin{array}{l}1.04 \\
(0.97-1.12)\end{array}$ & $\begin{array}{l}1.47 * * \\
(1.28-1.68)\end{array}$ & $\begin{array}{l}1.22^{*} \\
(1.08-1.39)\end{array}$ & $\begin{array}{l}1.12 * \\
(1.05-1.20)\end{array}$ & $\begin{array}{l}1.15 \\
(0.96-1.36)\end{array}$ & $\begin{array}{l}1.17 * * \\
(1.09-1.26)\end{array}$ & $\begin{array}{l}1.09 \\
(1.01-1.17)\end{array}$ & \begin{tabular}{|l}
$1.20^{* *}$ \\
$(1.11-1.30)$
\end{tabular} \\
\hline Concentrating & $\begin{array}{l}1.04 \\
(0.88-1.24)\end{array}$ & $\begin{array}{l}1.19 \\
(0.79-1.78)\end{array}$ & $\begin{array}{l}0.97 \\
(0.65-1.47) \\
\end{array}$ & $\begin{array}{l}1.07 \\
(0.90-1.27)\end{array}$ & $\begin{array}{l}1.01 \\
(0.60-1.71)\end{array}$ & $\begin{array}{l}1.36 * \\
(1.14-1.63)\end{array}$ & $\begin{array}{l}1.16 \\
(0.95-1.42)\end{array}$ & \begin{tabular}{|l|}
1.10 \\
$(0.90-1.35)$ \\
\end{tabular} \\
\hline Depression & $\begin{array}{l}0.93 \\
(0.85-1.02) \\
\end{array}$ & $\begin{array}{l}1.50 * * \\
(1.28-1.76)\end{array}$ & $\begin{array}{l}1.21 \\
(1.1 .04-1.42) \\
\end{array}$ & $\begin{array}{l}1.00 \\
(0.91-1.09) \\
\end{array}$ & $\begin{array}{l}1.16 \\
(0.94-1.43) \\
\end{array}$ & $\begin{array}{l}1.22 * * \\
(1.12-1.32)\end{array}$ & $\begin{array}{l}1.14^{*} \\
(1.04-1.25)\end{array}$ & \begin{tabular}{|l|}
1.06 \\
$(0.97-1.18)$ \\
\end{tabular} \\
\hline Seeing & $\begin{array}{l}0.92 \\
(0.69-1.24)\end{array}$ & $\begin{array}{l}1.75 \\
(1.08-2.82)\end{array}$ & $\begin{array}{l}1.26 \\
(0.70-2.28) \\
\end{array}$ & $\begin{array}{l}1.12 \\
(0.87-1.45)\end{array}$ & $\begin{array}{l}1.56 \\
(0.96-2.51)\end{array}$ & $\begin{array}{l}1.43 \\
(1.09-1.88)\end{array}$ & $\begin{array}{l}1.20 \\
(0.88-1.63)\end{array}$ & $\begin{array}{l}1.20 \\
(0.90-1.61)\end{array}$ \\
\hline Walking $100 \mathrm{~m}$ & $\begin{array}{l}0.89 \\
(0.75-1.05)\end{array}$ & $\begin{array}{l}1.47 \\
(1.09-1.96)\end{array}$ & \begin{tabular}{|l|}
1.05 \\
$(0.76-1.46)$ \\
\end{tabular} & $\begin{array}{l}1.10 \\
(0.94-1.28)\end{array}$ & $\begin{array}{l}1.43 \\
(0.98-2.09)\end{array}$ & $\begin{array}{l}1.19 \\
(1.01-1.40)\end{array}$ & $\begin{array}{l}0.97 \\
(0.80-1.17)\end{array}$ & \begin{tabular}{|l|}
1.16 \\
$(0.97-1.39)$ \\
\end{tabular} \\
\hline Walking 500m & $\begin{array}{l}0.88 \\
(0.77-1.00)\end{array}$ & $\begin{array}{l}1.24 \\
(0.95-1.61)\end{array}$ & \begin{tabular}{|l|}
0.95 \\
$(0.72-1.26)$ \\
\end{tabular} & $\begin{array}{l}1.11 \\
(0.98-1.26)\end{array}$ & $\begin{array}{l}1.27 \\
(0.90-1.78)\end{array}$ & $\begin{array}{l}1.11 \\
(0.97-1.28)\end{array}$ & $\begin{array}{l}0.90 \\
(0.76-1.06)\end{array}$ & $\begin{array}{l}1.07 \\
(0.92-1.25) \\
\end{array}$ \\
\hline Making friends & $\begin{array}{l}0.85 \\
(0.67-1.07)\end{array}$ & $\begin{array}{l}1.52 \\
(1.03-2.23)\end{array}$ & \begin{tabular}{|l|}
$1.67^{*}$ \\
$(1.17-2.40)$
\end{tabular} & $\begin{array}{l}0.98 \\
(0.79-1.22)\end{array}$ & $\begin{array}{l}1.20 \\
(0.54-2.69)\end{array}$ & $\begin{array}{l}1.17 \\
(0.94-1.45)\end{array}$ & $\begin{array}{l}1.30 \\
(1.05-1.62)\end{array}$ & \begin{tabular}{|l|}
1.02 \\
$(0.79-1.31)$ \\
\end{tabular} \\
\hline $\begin{array}{l}\text { Being understood } \\
\text { (outside) }\end{array}$ & $\begin{array}{l}0.60 * \\
(0.43-0.84)\end{array}$ & $\begin{array}{l}0.57 \\
(0.16-1.56)\end{array}$ & $\begin{array}{l}0.91 \\
(0.41-2.04)\end{array}$ & $\begin{array}{l}1.20 \\
(0.89-1.64)\end{array}$ & $\begin{array}{l}0.67 \\
(0.35-1.29)\end{array}$ & $\begin{array}{l}1.13 \\
(0.78-1.62)\end{array}$ & $\begin{array}{l}1.17 \\
(0.81-1.70)\end{array}$ & $\begin{array}{l}1.11 \\
(0.66-1.61)\end{array}$ \\
\hline Self-care & $\begin{array}{l}0.57^{* *} \\
(0.43-0.77)\end{array}$ & $\begin{array}{l}0.77 \\
(0.32-1.86)\end{array}$ & $\begin{array}{l}1.96 \\
(1.15-3.32)\end{array}$ & $\begin{array}{l}1.17 \\
(0.88-1.56)\end{array}$ & $\begin{array}{l}0.48 \\
(0.12-1.92)\end{array}$ & $\begin{array}{l}0.84 \\
(0.55-1.27)\end{array}$ & $\begin{array}{l}0.69 \\
(0.43-1.09)\end{array}$ & $\begin{array}{l}0.82 \\
(0.54-1.24) \\
\end{array}$ \\
\hline
\end{tabular}




\begin{tabular}{|c|c|c|c|c|c|c|c|c|}
\hline $\begin{array}{l}\text { Being understood (in } \\
\text { their home) }\end{array}$ & $\begin{array}{l}0.46 * * \\
(0.30-0.71)\end{array}$ & $\begin{array}{l}0.84 \\
(0.32-2.25)\end{array}$ & $\begin{array}{l}0.89 \\
(0.37-2.13)\end{array}$ & $\begin{array}{l}1.03 \\
(0.72-1.48)\end{array}$ & $\begin{array}{l}0.76 \\
(0.25-2.37)\end{array}$ & $\begin{array}{l}1.05 \\
(0.70-1.58)\end{array}$ & $\begin{array}{l}1.03 \\
(0.67-1.58)\end{array}$ & $\begin{array}{l}1.06 \\
(0.69-1.62)\end{array}$ \\
\hline
\end{tabular}

